University of Nebraska - Lincoln

DigitalCommons@University of Nebraska - Lincoln

5-23-2019

\title{
Modeled El Niño-Southern Oscillation Effects on Grain Sorghum under Varying Irrigation Strategies and Cultural Practices
}

\author{
R. L. Baumhardt \\ USDA-Agricultural Research Service, R.Louis.Baumhardt@ars.usda.gov \\ R. C. Schwartz \\ USDA-Agricultural Research Service, robert.schwartz@ars.usda.gov \\ G.W Marek \\ USDA-Agricultural Research Service \\ J.E. Moorhead \\ USDA-Agricultural Research Service
}

Follow this and additional works at: https://digitalcommons.unl.edu/usdaarsfacpub

Baumhardt, R. L.; Schwartz, R. C.; Marek, G.W; and Moorhead, J.E., "Modeled El Niño-Southern Oscillation Effects on Grain Sorghum under Varying Irrigation Strategies and Cultural Practices" (2019). Publications from USDA-ARS / UNL Faculty. 2135.

https://digitalcommons.unl.edu/usdaarsfacpub/2135

This Article is brought to you for free and open access by the U.S. Department of Agriculture: Agricultural Research Service, Lincoln, Nebraska at DigitalCommons@University of Nebraska - Lincoln. It has been accepted for inclusion in Publications from USDA-ARS / UNL Faculty by an authorized administrator of DigitalCommons@University of Nebraska - Lincoln. 


\title{
Modeled El Niño-Southern Oscillation Effects on Grain Sorghum under Varying Irrigation Strategies and Cultural Practices
}

\author{
R.L. Baumhardt,* R.C. Schwartz, G.W Marek, and J.E. Moorhead
}

\begin{abstract}
Equatorial sea surface temperatures vary systematically to cause the El Niño southern oscillation (ENSO) that produces predictable weather patterns in North America and may permit longrange climate predictions and eventual proactive summer crop irrigation management. The declining Ogallala Aquifer in the Southern High Plains and consequently limited well capacities challenge producers to adapt cropping practices for irrigation that doesn't meet crop water demand. Our objective was to evaluate sorghum [Sorghum bicolor (L.) Moench] yield response to ENSO climate-informed management of cultural practices and irrigation strategies on a Pullman soil (fine, mixed, superactive, thermic Torrertic Paleustoll). We used the simulation model SORKAM and long-term (1961-2000) weather records from Bushland, TX, classified by ENSO phase to calculate sorghum grain yields for all combinations of irrigation levels $(0.0,2.5,3.75$, or $\left.5.0 \mathrm{~mm} \mathrm{~d}^{-1}\right)$, planting day of year (DOY $\left.=135,156,176\right)$, and cultivar maturity (early, $95 \mathrm{~d}$; medium, $105 \mathrm{~d}$; late, 120 d). Using the September-November Oceanic Niño Index (ONI) to identify ENSO phase, La Niña years had $50 \mathrm{~mm}$ less precipitation and a corresponding $14.5 \%$ reduction in overall yield to $4550 \mathrm{~kg} \mathrm{ha}^{-1}$ for sorghum planted at 16 plants $\mathrm{m}^{-2}$ population. Late maturing cultivars and late planting led to sorghum freeze injury and reduced yields regardless of ENSO phase. While yields consistently increased with irrigation, we conclude that concentrating water to irrigate an area partitioned 2:1 or 1:1 at 3.75- or $5.0-\mathrm{mm}$ $\mathrm{d}^{-1}$ with complementary dryland produced $>30 \%$ more grain, overall, than uniformly irrigating an area at $2.5 \mathrm{~mm} \mathrm{~d}^{-1}$.
\end{abstract}

\section{Core Ideas}

- Maturing Oceanic Niño Index identified La Niña years with less rain and yield.

- Increased irrigation plus rain improved yield but water use efficiency plateaued.

- Irrigation of partitioned areas with dryland improved yield independent of El Niño southern oscillation phase.

This document is a U.S. government work and is not subject to copyright in the United States.

Published in Agron. J. 111:1913-1922 (2019)

doi:10.2134/agronj2018.09.0616

Copyright $\odot 2019$ The author(s). Re-use requires permission from the publisher.
ح HE SEMIARID climate of the US High Plains physiographic region that extends from Texas to South Dakota (Gutentag et al., 1984) receives an average of $<500 \mathrm{~mm}$ precipitation annually, providing from 40 to $80 \%$ of the potential evapotranspiration (Follett et al., 2012) and necessitating irrigation to meet crop water demand. Because irrigation from the Ogallala (High Plains) Aquifer that began in the 1950 s exceeds the practically negligible recharge south of Nebraska, the resulting spatially weighted water table decline since pre-development ranges from $3.8 \mathrm{~m}$ in Oklahoma to 12.5 $\mathrm{m}$ in Texas (Stewart, 2003; McGuire, 2017). About $90 \%$ of groundwater withdrawals in High Plains states was used for irrigation, but other competing groundwater allocations include municipal water (4-6\%) and livestock, industrial, or mining uses (1-3\%) that may vary locally (Wagner, 2012; Scanlon et al., 2017; Dieter et al., 2018). For example, $91 \%$ of groundwater use in the Permian Basin is for irrigation with 3\% used for hydraulic fracturing oil wells (mining), but at a water-use/oil-recovery ratio of 1.0 in the adjoining Delaware Basin (Scanlon et al., 2017) the recent discoveries initially producing up to $1530 \mathrm{~m}^{3}$ oil daily (Darbonne, 2018) can expand competition for water. Increased competition for water resources in addition to the declining water table effects encourage innovative irrigation strategies.

A consequence of the declining groundwater table and aquifer saturated thickness is decreasing irrigation well capacity that may be insufficient to meet crop demand. This has been offset by improved irrigation scheduling based on evapotranspiration (ET) replacement (Howell, 2001), more efficient application methods such as subsurface drip or Low Energy Precision Application (Colaizzi et al., 2009), and managed deficit irrigation that defers water application to critical growth stages (Bell

USDA-Agricultural Research Service, Conservation and Production Research Lab., P.O. Drawer 10, Bushland, TX 79012-0010. The USDA prohibits discrimination in all its programs and activities on the basis of race, color, national origin, age, disability, and where applicable, sex, marital status, familial status, parental status, religion, sexual orientation, genetic information, political beliefs, reprisal, or because all or part of an individual's income is derived from any public assistance program. (Not all prohibited bases apply to all programs.) Persons with disabilities who require alternative means for communication of program information (Braille, large print, audiotape, etc.) should contact USDA's TARGET Center at (202) 720-2600 (voice and TDD). To file a complaint of discrimination, write to USDA, Director, Office of Civil Rights, 1400 Independence Avenue, S.W., Washington, DC. 20250-9410, or call (800) 795-3272 (voice) or (202) 720-6382 (TDD). USDA is an equal opportunity provider and employer. Received 27 Sept. 2018. Accepted 6 Mar. 2019. *Corresponding author (r.louis.baumhardt@ars.usda.gov).

Abbreviations: DOY, day of year; ENSO, El Niño southern oscillation; ET, evopotranspiration; HI, harvest index; ONI, Oceanic Niño Index; $\mathrm{PM}$, physiological maturity; WUE, water use efficiency ( $\mathrm{kg} \mathrm{m}-3)$. 
et al., 2018). Irrigation would be recommended for managed deficit irrigation during growing point differentiation or the "boot" (panicle exertion) critical growth stages (Stichler et al., 1997; Vanderlip et al., 1998; Gerik et al., 2003). Baumhardt and Howell (2006) pointed out, however, that deficit irrigation is often applied uniformly during the growing season because of the practical limitation imposed by irrigation well capacity that precludes growth stage specific large irrigations. Planting date and cultivar maturity combine to determine growing season duration that increases yield proportionately when irrigation well capacity meets sorghum ET demand (Vanderlip et al., 1998). Under deficit irrigation at rates of $\leq 2.5 \mathrm{~mm} \mathrm{~d}^{-1}$, grain sorghum water use efficiency and yield for the Southern High Plains was achieved with early planting of early-maturing cultivars (Baumhardt and Howell, 2006). Converting from uniform field deficit irrigation (water spreading) to partitioned field irrigation that concentrates water resources to better meet crop ET needs but includes a dryland area, increased simulated yield and water use efficiency (WUE) of both grain sorghum and cotton [Gossypium hirsutum (L.)] (Baumhardt et al., 2007; Nair et al., 2013; Baumhardt et al., 2015). Integration of growing season rain and irrigation for management strategies differing by planting date and cultivar may benefit from climate predictions.

Greater reliance on growing season precipitation represents a means to reduce irrigation water withdrawals and the subsequent depletion of the Ogallala Aquifer, but precipitation on the southern High Plains is erratic in both distribution and amount that varies from 89 to $580 \mathrm{~mm}$ per year (Baumhardt and SalinasGarcia, 2006). A climate analysis by Mauget and Upchurch (1999) identified favorable fall and winter precipitation during the El Niño phase, warm $\left(>0.5^{\circ} \mathrm{C}\right)$ sea surface temperature anomalies conditions, and below average precipitation during the $\operatorname{cool}\left(<-0.5^{\circ} \mathrm{C}\right)$ La Niña phase. They observed no change in summer precipitation during the El Niño phase, but the corresponding rains during La Niña phases decreased after June. Proactive wheat management was possible on the Southern High Plains for developing El Niño or La Niña phases that coincided with timely decisions regarding planting date and fertilizer management, (Mauget et al., 2009). Using ENSO phase for long-range climate predictions may permit proactive summer crop and irrigation management (Jones et al., 2000; Baumhardt et al., 2015).

In a 1954-2011 field experiment, Baumhardt et al. (2016) reported mean sorghum growing season rain increased from $193 \mathrm{~mm}$ for La Niña years to $236 \mathrm{~mm}$ for Neutral and $262 \mathrm{~mm}$ for El Niño phase years, but differences in rain amount or the corresponding measured yield increases of 500 and $800 \mathrm{~kg} \mathrm{ha}^{-1}$ were not significant. Preliminary (1961-2000) crop growth simulations using a 12 plant $\mathrm{m}^{-2}$ population and standardized field and cultivar conditions, revealed greater sorghum yield trends with grain yields for Neutral and El Niño phases that were significantly greater than for the La Niña phase. We therefore hypothesize that simulated sorghum yields using longterm weather as input will reveal ENSO phase specific deficit irrigation strategies that increase grain yields. Our objective was to evaluate sorghum grain yield response to ENSO climate informed management of varying cultural practices and irrigation allocation strategies. To achieve this we simulated sorghum response to planting date, cultivar maturity, and irrigation level for all ENSO phases during a $40 \mathrm{yr}$ period then computed the weighted average yield for either spreading a fixed water resource to deficit irrigate a large area or concentrating irrigation on a smaller area combined with a complementary dryland area.

\section{MATERIALS AND METHODS}

Grain sorghum growth and yield was simulated according to the methods of Baumhardt et al. (2005) using the model SORKAM (Rosenthal et al., 1989) as updated to version 2000 (W.D. Rosenthal and R.L. Vanderlip, personal communication, 2000). Model required daily weather input of solar irradiance $\left(\mathrm{MJ} \mathrm{m}^{-2}\right)$, maximum and minimum air temperature $\left({ }^{\circ} \mathrm{C}\right)$, and precipitation ( $\mathrm{mm}$ ) was supplied from records at the USDAARS, Conservation and Production Research Laboratory, Bushland, TX (35 $11^{\prime} \mathrm{N}, 102^{\circ} 5^{\prime} \mathrm{W} ; 1170 \mathrm{~m}$ elevation) for growing seasons during 1961-2000. Soil fertility was necessarily assumed to be adequate for sorghum because SORKAM does not simulate nutrient effects on crop growth and yield. The simulations were performed for a 1.8-m deep Pullman clay loam (fine, mixed, superactive, thermic Torrertic Paleustoll) profile divided into nine layers having similar porosity and plant available water (Baumhardt et al., 2005). For comparison among alternative management practices as replicated by years, the soil profile was reset each year to a uniform water content of $160 \mathrm{~mm}$, which was the long-term median soil water observed at planting for stubble-mulch tillage (Baumhardt et al., 2017). Maximum sorghum rooting depth was not restricted within the $1.8 \mathrm{~m}$ soil profile depth, which is consistent with observed rooting to depths $>1.5 \mathrm{~m}$ for dryland sorghum grown on a Pullman soil at Bushland (Moroke et al., 2005). Soil water evaporation was calculated by the Priestley-Taylor method with an overall 1.45 scale factor, after Howell et al. (1989), using constants of 0.19 for albedo, $9.9 \mathrm{~mm}$ for $\mathrm{U}$ (stage 1) and $7.8 \mathrm{~mm} \mathrm{~d}^{-1}$ for $\mathrm{C}$ (stage 2) as reported by Steiner (1989) for the two stages of soil water evaporation. Runoff was calculated using the measured SCS curve number of 82 for sorghum reported by Hauser and Jones (1991).

\section{Crop Simulations}

Our simulations began $2 \mathrm{wk}$ before the scenario planting date for all possible combinations of three cultivar maturity levels, three planting dates, and four water application levels. Scenario water levels ranged from dryland (rain only) to rain + irrigation totaling 2.5, 3.75, and $5.0 \mathrm{~mm} \mathrm{~d}^{-1}$ and were applied, independently of crop growth stage, in $10 \mathrm{~d}$ intervals using a 25 , 37.5 , or $50 \mathrm{~mm}$ maximum application depth. These irrigation levels represent a range of well pumping capacities approximating 3, 4.6, and 6.1 $\mathrm{L} \mathrm{min}^{-1} \mathrm{ha}^{-1}$, which are consistent with progressively more productive irrigation wells in the region. We selected three generic cultivars that produce 15,17 , or 19 leaves to represent early-, medium-, and late-maturing cultivars requiring $\sim 95,105$, and $120 \mathrm{~d}$ to reach maturity, which were planted 15 May (early), 5 June (normal), and 25 June (late) for evaluating a broad range of growing season durations on deficit irrigated sorghum performance. A population of 16 plants $\mathrm{m}^{-2}$ in single rows $0.76 \mathrm{~m}$ apart was selected as an intermediate plant density for transitioning from irrigated to dryland production. The resulting 36 simulation scenarios were evaluated for each of $40 \mathrm{yr}$ of weather records for a total of 1440 simulations. The SORKAM simulations continued until the earlier date of crop physiological maturity or a killing frost, when grain yield and 
water use estimated from growing season rain, irrigation, and soil water were determined.

Inferring alternative cultural practice effects on grain sorghum growth, yield, and water use efficiency is critically dependent on the validity of SORKAM to simulate plant responses under variable growing conditions. In addition to numerous reports validating SORKAM (Rosenthal and Gerik, 1990; Heiniger et al., 1997; Xie et al., 2001), Baumhardt and Howell (2006) also validated SORKAM calculated grain sorghum yields for the Pullman soil at Bushland using location recorded weather and actual cropping conditions (e.g., planting date). Their simulated grain yields averaged $\sim 4 \%$ more than observed yields $\left(r^{2}=0.70\right.$, RMSE $\left.=903.5 \mathrm{~kg} \mathrm{ha}^{-1}\right)$ of the corresponding similarly planted late- and medium-maturity hybrids from a 1984-1998 wheat-sorghum-fallow rotation study (Jones and Popham, 1997). The corresponding water use averaged 470 $\mathrm{mm}$ and was not significantly different $(P=0.10)$ from the SORKAM simulated value of $507 \mathrm{~mm}$ according to a paired $t$ test (Baumhardt and Howell, 2006). These successful yield and water use estimations indicated SORKAM adequately simulates these factors throughout a broad range of climate and growing conditions and no further validation was performed.

\section{El Niño Southern Oscillation Classification}

The efficacy of using ENSO phase as a tool for climate informed management was evaluated using the readily available monthly Oceanic Niño Index (ONI) of the Niño 3.4 region $\left(5^{\circ} \mathrm{N}-5^{\circ} \mathrm{S}, 120^{\circ}-170^{\circ} \mathrm{W}\right)$ published by the National Weather Service Climate Prediction Center (CPC, 2018). The ONI classifies ENSO phases based on deviations in observed equatorial sea surface temperature from reference temperatures of centered 30 -yr periods that are updated every 5 yr to account for any temperature bias due to climate change. A maturing ENSO phase determined from the ONI 3-mo period from September through November was used as the basis of comparison. Warm El Niño phase conditions occur when the ONI exceeded $0.5^{\circ} \mathrm{C}$, cold La Niña conditions are designated by ONI values less than $-0.5^{\circ} \mathrm{C}$ and all exceptions to those conditions were ENSO phase Neutral. The resulting years for each ENSO phase listed by Baumhardt et al. (2016) for 1961-2000 comprised 14 yr for the Neutral phase and 13 yr each for the El Niño and La Niña phases.

\section{Analyses}

Sorghum growth, grain yield, water use (i.e., sum of precipitation, irrigation and change in soil water), and the WUE, calculated as the ratio of yield to water use, were evaluated for each of 36 simulation scenarios appearing each year. Climatic variability from the unique weather conditions, e.g., rainfall and temperature, specific to a simulated growing season (19612000) provided the source of random experimental error to test SORKAM projected crop growth response of each scenario. We compared ENSO phase, irrigation capacity, cultivar maturity, and planting date fixed effects on modeled sorghum performance according to a factorial arrangement of a completely randomized design using SAS glimmix ANOVA procedures (SAS Institute, 2014). We subsequently isolated simulated sorghum water use, growth, and yield performance by specific ENSO phase with years as a random effect to better compare cultivar maturity, planting dates, and irrigation fixed effects within each phase. Contrasts (estimated with the slice option in the mixed model LS-means statement) were used to evaluate simple within subject effects. Unless specified otherwise, all statistical analysis effects were declared significant at the 0.05 probability level.

\section{RESULTS AND DISCUSSION}

\section{Growing Season Conditions}

Precipitation for the 1961-2000 simulated growing seasons averaged $240 \mathrm{~mm}$ but was subsequently partitioned to reveal the effects of ENSO phase and crop management that includes planting date, cultivar maturity, and irrigation level. The $207 \mathrm{~mm}$ mean precipitation for the La Niña ENSO phase was a significant $(P<0.01) 20 \%$ reduction from the $260 \mathrm{~mm}$ average for the Neutral and El Niño phases. The growing season extending earlier planting date and later cultivar maturity were associated with significantly $(P<0.01)$ greater seasonal precipitation (Table 1) regardless of ENSO phase probably because potentially longer frost-free periods have been weakly correlated to ENSO indices (McCabe et al., 2015). Because water deficit stress can delay growth and extend the growing season the observed seasonal precipitation was significantly greater for dryland, $0.00 \mathrm{~mm} \mathrm{~d}^{-1}$ irrigation, than for any of the 2.50, 3.75, or $5.00 \mathrm{~mm} \mathrm{~d}^{-1}$ irrigation levels except for the El Niño phase.

The overall $40 \mathrm{yr}$ simulated growing season time to anthesis ranged from $79 \mathrm{~d}$ for the La Niña phase to the significantly $(P<0.01)$ shorter $75-\mathrm{d}$ average for El Niño and Neutral phases with all phases maturing about $40 \mathrm{~d}$ later. For dryland sorghum, our simulated anthesis and physiological maturity (PM) was delayed $(P<0.01$ for both anthesis and $P M) \sim 2$ wk during the drier La Niña phase compared with Neutral and El Niño phases (Table 1). Although sorghum anthesis and PM for all ENSO phases were significantly $(P<0.01)$ later for dryland, these became progressively earlier for the $2.50 \mathrm{~mm} \mathrm{~d}^{-1}$ and 3.75 - or $5.00-\mathrm{mm} \mathrm{d}^{-1}$ irrigation rates because delays in sorghum development due to water stress were reduced or prevented by the added water. As might be expected, progressively later maturing cultivars significantly $(P<0.01)$ extended the growing season duration for both anthesis and PM for each of the ENSO phases, but we simulated earlier PM for mid (June 5) planting dates for each ENSO phase. For all ENSO phases, an interaction between irrigation level and either the planting date or cultivar maturity delayed PM of sorghum with earlier planting dates or cultivar maturities and the lower dryland or $2.5 \mathrm{~mm} \mathrm{~d}^{-1}$ irrigation levels. The delay in grain sorghum development can shift the growing season of some irrigation combinations with planting date or cultivar maturity to later months that typically receive less precipitation and, consequently, cause greater reliance on irrigation and exposure to potential freeze injuries.

Anthesis typically occurred during mid-August to mid-September and, typically, was early enough in the growing season to avoid freeze events; however, anthesis freeze injuries did occur in $2.7 \%$ of the simulations or 38 events with two-thirds of those ( 25 events) during the drier La Niña phase $(P<0.01)$. By contrast, PM freeze injuries that represent a concern due to potential yield reduction were observed in $22 \%$ or 312 of the simulations and were, in the absence of a significant ENSO effect, evenly divided among the phases (Table 1). Within any ENSO phase, PM freeze injury for sorghum planted DOY176 averaged $77 \%$ of these 312 events but were practically 
Table I. The ENSO phase specific mean time to reach anthesis and physiological maturity and the seasonal rain and irrigation at maturity for scenario planting date (PD), irrigation capacity (I), and cultivar maturity (C) main effects, with the corresponding ANOVA significance levels. $\dagger$

\begin{tabular}{|c|c|c|c|c|c|c|c|c|c|c|c|c|}
\hline \multirow[b]{3}{*}{ Effect } & \multirow{2}{*}{\multicolumn{3}{|c|}{$\begin{array}{l}\text { Seasonal rain } \\
\text { ENSO phase }\end{array}$}} & \multirow{2}{*}{\multicolumn{3}{|c|}{$\begin{array}{c}\text { Days to anthesis } \\
\text { ENSO phase }\end{array}$}} & \multirow{2}{*}{\multicolumn{3}{|c|}{$\begin{array}{c}\text { Days to maturity } \\
\text { ENSO phase }\end{array}$}} & \multirow{2}{*}{\multicolumn{3}{|c|}{$\begin{array}{c}\text { Freeze by maturity } \\
\text { ENSO phase }\end{array}$}} \\
\hline & & & & & & & & & & & & \\
\hline & La Niña & Neutral & El Niño & La Niña & Neutral & El Niño & La Niña & Neutral & El Niño & La Niña & Neutral & El Niño \\
\hline Planting date, DOY & \multicolumn{3}{|c|}{$\mathrm{mm}$} & & & 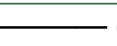 & & & & \multicolumn{3}{|c|}{ Events } \\
\hline 135 & 223 af & 291 a & $287 \mathrm{a}$ & $86 a$ & $81 \mathrm{a}$ & $80 a$ & $121 \mathrm{a}$ & $118 \mathrm{a}$ & $117 \mathrm{a}$ & $13 \mathrm{~b}$ & $10 \mathrm{~b}$ & $5 \mathrm{~b}$ \\
\hline 156 & $204 \mathrm{~b}$ & $25 \mathrm{Ib}$ & $26 \mathrm{lb}$ & $77 \mathrm{~b}$ & $72 b$ & $72 b$ & $116 \mathrm{~b}$ & $\mathrm{Il} 4 \mathrm{~b}$ & $\mathrm{II} 4 \mathrm{~b}$ & $19 b$ & $13 \mathrm{~b}$ & $\mathrm{II} b$ \\
\hline 176 & $193 \mathrm{c}$ & $233 c$ & $235 c$ & $74 b$ & $71 \mathrm{~b}$ & $70 \mathrm{~b}$ & $120 \mathrm{a}$ & $119 a$ & $117 \mathrm{a}$ & 75 a & $91 \mathrm{a}$ & $75 \mathrm{a}$ \\
\hline \multicolumn{13}{|l|}{ Irrigation, $\mathrm{mm} \mathrm{d}^{-1}$} \\
\hline 0.0 (dryland) & 229 a & $269 \mathrm{a}$ & $264 \mathrm{a}$ & $99 \mathrm{a}$ & $85 \mathrm{a}$ & $80 \mathrm{a}$ & $132 \mathrm{a}$ & $123 \mathrm{a}$ & $119 a$ & $54 \mathrm{a}$ & $46 \mathrm{a}$ & $31 \mathrm{a}$ \\
\hline 2.5 & $204 b$ & $257 \mathrm{~b}$ & $260 \mathrm{a}$ & $76 b$ & $74 \mathrm{~b}$ & $74 b$ & $118 \mathrm{~b}$ & $116 b$ & $115 \mathrm{~b}$ & $21 \mathrm{~b}$ & $24 \mathrm{~b}$ & $20 \mathrm{~b}$ \\
\hline 3.75 & $196 \mathrm{~b}$ & $252 b$ & $259 a$ & $70 \mathrm{c}$ & $70 \mathrm{c}$ & $71 \mathrm{c}$ & $113 \mathrm{c}$ & $\mathrm{I} 14 \mathrm{~b}$ & $114 \mathrm{~b}$ & $16 \mathrm{~b}$ & $22 b$ & $19 b$ \\
\hline 5.0 & $199 \mathrm{~b}$ & $255 \mathrm{~b}$ & $262 \mathrm{a}$ & $70 c$ & $70 c$ & $71 \mathrm{c}$ & $114 c$ & $115 b$ & $115 b$ & $16 b$ & $22 b$ & $21 \mathrm{~b}$ \\
\hline \multicolumn{13}{|l|}{ Cultivar maturity } \\
\hline Early & $188 \mathrm{c}$ & $244 c$ & $247 c$ & $66 c$ & $65 c$ & $65 c$ & $106 c$ & $107 c$ & $106 \mathrm{c}$ & $7 c$ & $8 c$ & $7 c$ \\
\hline Medium & $210 \mathrm{~b}$ & $258 \mathrm{~b}$ & $263 \mathrm{~b}$ & $80 \mathrm{~b}$ & $74 \mathrm{~b}$ & $74 b$ & $121 \mathrm{~b}$ & $117 b$ & $116 \mathrm{~b}$ & $42 \mathrm{~b}$ & $40 \mathrm{~b}$ & $31 \mathrm{~b}$ \\
\hline Late & $222 \mathrm{a}$ & $273 \mathrm{a}$ & $274 a$ & $91 \mathrm{a}$ & $84 \mathrm{a}$ & $82 \mathrm{a}$ & $|3| a$ & $126 \mathrm{a}$ & $125 \mathrm{a}$ & $58 \mathrm{a}$ & $66 \mathrm{a}$ & $53 \mathrm{a}$ \\
\hline ignificance & 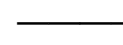 & $-P>F$ & - & 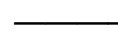 & $-P>F$. & 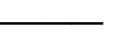 & 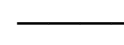 & $-P>F$ & & & $-P>F$. & 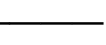 \\
\hline PD & $<0.01$ & $<0.01$ & $<0.01$ & $<0.01$ & $<0.01$ & $<0.01$ & $<0.01$ & $<0.01$ & $<0.01$ & $<0.01$ & $<0.01$ & $<0.01$ \\
\hline I & $<0.01$ & 0.02 & 0.73 & $<0.01$ & $<0.01$ & $<0.01$ & $<0.01$ & $<0.01$ & $<0.01$ & $<0.01$ & $<0.01$ & 0.01 \\
\hline$P D \times 1$ & 0.10 & 0.31 & 0.98 & 0.65 & 0.21 & 0.99 & $<0.01$ & $<0.01$ & $<.03$ & 0.40 & 0.54 & 0.68 \\
\hline C & $<0.01$ & $<0.01$ & $<0.01$ & $<0.01$ & $<0.01$ & $<0.01$ & $<0.01$ & $<0.01$ & $<0.01$ & $<0.01$ & $<0.01$ & $<0.01$ \\
\hline$C \times P D$ & 0.09 & 0.44 & 0.25 & 0.94 & 0.89 & 0.97 & 0.19 & 0.01 & 0.05 & $<0.01$ & $<0.01$ & $<0.01$ \\
\hline$C \times 1$ & $<0.01$ & $<0.01$ & $<0.01$ & $<0.01$ & $<0.01$ & $<0.01$ & $<0.01$ & $<0.01$ & $<0.01$ & $<0.01$ & 0.31 & 0.22 \\
\hline$C \times I \times P D$ & 0.99 & 0.99 & $>0.99$ & $>0.99$ & $>0.99$ & $>0.99$ & 0.84 & 0.69 & 0.67 & 0.97 & 0.52 & 0.99 \\
\hline
\end{tabular}

$\dagger$ ENSO, El Niño southern oscillation; DOY, day of year; PD, planting date; I, irrigation; C, cultivar.

$\ddagger$ Effect means within columns followed by the same letter are not significantly different, $P=0.05$.

exclusive to simulation scenarios with irrigations $>0 \mathrm{~mm} \mathrm{~d}^{-1}$ that increased vegetative growth. Likewise, the DOY-176 late planting led to almost half of the 38 simulated anthesis freeze injuries, highlighting the greater risk due to late planting. Approximately half of the PM and all of the anthesis freeze injuries were simulated using the $0.00 \mathrm{~mm} \mathrm{~d}^{-1}$ irrigation level regardless of the ENSO phase because of growth delays related to water stress (Donatelli et al., 1992; Farré and María Faci, 2006; Bell et al., 2018). Medium and late maturing cultivars incurred progressively greater, $36 \%$ and $57 \%$, PM freeze injury because of the cultivar specific delayed maturity (Table 1).

\section{Crop Water Use}

The overall combined seasonal rain and irrigation means ranged from $368 \mathrm{~mm}$ for the La Niña to the significantly $(P<$ 0.01 ) larger $390 \mathrm{~mm}$ for Neutral and $383 \mathrm{~mm}$ for El Niño phases. Within each ENSO phase we show, by irrigation level, all possible combinations of cultivar maturity and planting date in Fig. 1. The extended growing season due to later maturing cultivars and earlier planting dates also increased cumulative rain as shown by the shaded column fractions. Because dryland, no irrigation, conditions also extended the growing season, rainfall increased $30 \mathrm{~mm}$ over the $200 \mathrm{~mm}$ average of all other irrigation levels for the La Niña phase. By contrast, rainfall for the extended dryland growing season of Neutral and El Niño phase years increased ranged from $10 \mathrm{~mm}$ to $0 \mathrm{~mm}$ over the corresponding 255 and $260 \mathrm{~mm}$ rainfall for irrigated simulation scenarios. For the drier La Niña phase, the increasing irrigation rates added water, averaged over planting date and cultivar maturity, in the amount of $95 \mathrm{~mm}$ at the lowest $2.50 \mathrm{~mm} \mathrm{~d}^{-1}$ irrigation level, increasing to $208 \mathrm{~mm}$ for $3.75 \mathrm{~mm} \mathrm{~d}^{-1}$ and $342 \mathrm{~mm}$ for $5.00 \mathrm{~mm} \mathrm{~d}^{-1}$.
Likewise, the irrigation applied during the wetter Neutral phase decreased to $69 \mathrm{~mm}$ for $2.50 \mathrm{~mm} \mathrm{~d}^{-1}, 164 \mathrm{~mm}$ for $3.75 \mathrm{~mm}$ $\mathrm{d}^{-1}$, and $293 \mathrm{~mm}$ for $5.00 \mathrm{~mm} \mathrm{~d}^{-1}$ and, for the El Niño phase, to slightly lower irrigation amounts of $53 \mathrm{~mm}, 152 \mathrm{~mm}$, and $283 \mathrm{~mm}$ for the corresponding irrigation levels. Seasonal rain plus irrigation for the $2.50 \mathrm{~mm} \mathrm{~d}^{-1}$ irrigation level averaged $312 \pm 12 \mathrm{~mm}$ across all ENSO phases, increasing to $410 \pm 6 \mathrm{~mm}$ for $3.75 \mathrm{~mm} \mathrm{~d}^{-1}$ and $545 \pm 2 \mathrm{~mm}$ for $5.00 \mathrm{~mm} \mathrm{~d}^{-1}$ irrigation levels, demonstrating that target supplemental irrigation levels were effectively managed independent of the ENSO phase.

Seasonal crop water use varied by ENSO phase, averaging $500 \mathrm{~mm}$ for La Niña compared with larger $(P<0.01) 520$ $\mathrm{mm}$ for Neutral and $530 \mathrm{~mm}$ for El Niño phases due, in part, to their receiving $50 \mathrm{~mm}$ more rain than La Niña. As previously noted for rainfall, those factors that limit growing season duration such as late planting or early maturing cultivars, subsequently, reduced crop water use within any ENSO phase (Fig. 2). For example, water use for later DOY-176 planted sorghum decreased often by $>65 \mathrm{~mm}$ to $468-493 \mathrm{~mm}$ from the 525-553 mm observed for DOY 135 planted sorghum depending on the ENSO phase. The progressively longer growing season for medium and late maturing cultivars similarly increased water use by 30 to $45 \mathrm{~mm}$ compared with the early maturing cultivar that used $474 \mathrm{~mm}$ during La Niña phase or an average of $500 \mathrm{~mm}$ for the Neutral and El Niño phases. It is not surprising that water use increased progressively as the irrigation levels increased from $0.00 \mathrm{~mm} \mathrm{~d}^{-1}$, dryland, to the rain plus supplemental irrigation of up to the $5.00 \mathrm{~mm} \mathrm{~d}^{-1}$ level (Fig. 2). That is, mean water use for the highest irrigation rate ranged from 601 to $610 \mathrm{~mm}$ across all ENSO phases or similar to that reported for Pullman soil by Tolk and Howell (2001), while dryland 



Fig. I. Combined seasonal rain (shaded fraction of columns) and irrigation for early, medium, and late maturing sorghum cultivars planted on day of year (DOY) 135, I56, and 176 for dryland and deficit irrigation of up to $2.5,3.75$, and $5.0 \mathrm{~mm} \mathrm{~d}^{-1}$ during all El Niño southern oscillation phases. Columns from common irrigation levels with the same letter are not significantly different, $P=0.05$

sorghum water use decreased by $210 \mathrm{~mm}$ to $395 \mathrm{~mm}$ during the La Niña phase and averaged $445 \mathrm{~mm}$ for the wetter Neutral and El Niño phases. Mean seasonal water use for the $2.50 \mathrm{~mm}$ $\mathrm{d}^{-1}$ irrigation rate averaged $\sim 480 \mathrm{~mm}$ across all ENSO phases, ranging from a low of $463 \mathrm{~mm}$ for the La Niña to a high of 487 $\mathrm{mm}$ for El Niño phases. Likewise, increasing irrigation to 3.75 $\mathrm{mm} \mathrm{d}^{-1}$ rate elevated mean seasonal water use to $550 \mathrm{~mm}$, ranging from a low of $544 \mathrm{~mm}$ for the La Niña ENSO phase up to $565 \mathrm{~mm}$ for the El Niño.

Seasonal water use increasingly relied on precipitation during wetter ENSO phases, ranging from $41 \%$ for the La Niña phase to $50 \%$ for the Neutral and El Niño phases. Regardless
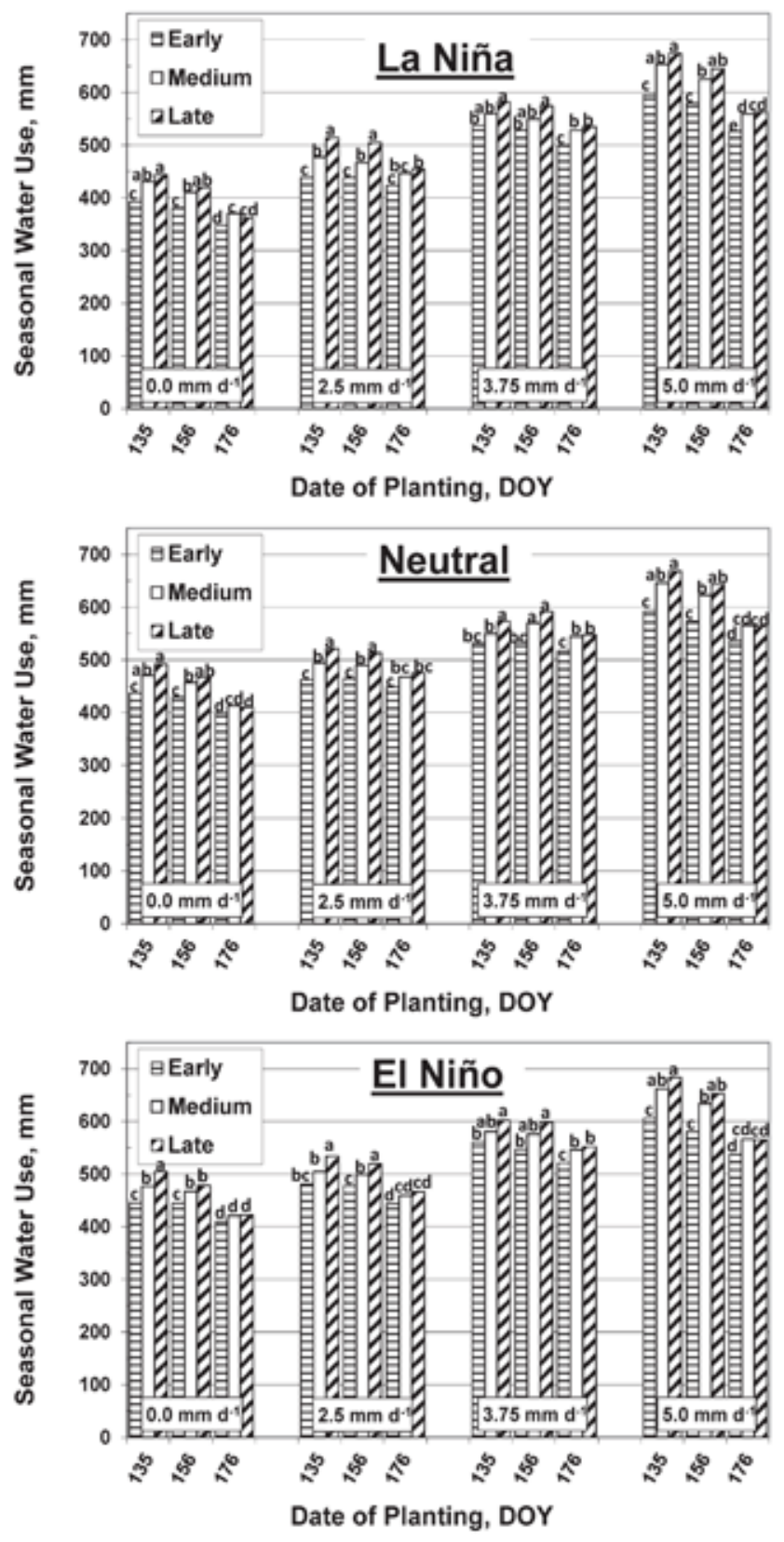

Fig. 2. Simulated (196I-2000) sorghum water use of early, medium, and late maturing cultivars planted on day of year (DOY) 135, I56, and 176 for dryland (rain only) and rain + deficit irrigation supplying up to $2.5,3.75$, and $5.0 \mathrm{~mm} \mathrm{~d}^{-1}$ during all El Niño southern oscillation phases. Columns from common irrigation levels with the same letter are not significantly different, $P=0.05$.

of ENSO phase, rain supplied $\sim 60 \%$ of dryland crop water use with the balance, $40 \%$, from soil water. As irrigation levels progressively increased from $2.50 \mathrm{~mm} \mathrm{~d}^{-1}$ up to $5.00 \mathrm{~mm} \mathrm{~d}^{-1}$, rain contributed proportionally less to crop water use, decreasing from 44 to $33 \%$ during the drier La Niña phase and from 53 to $43 \%$ during wetter Neutral and El Niño phases. Consequently, the fraction of crop water use supplied by the progressively higher irrigation levels increased from 21 to $60 \%$ for the $\mathrm{La}$ Niña phase compared with similar increases from 14 to $49 \%$ for Neutral and 11 to $46 \%$ for El Niño phases. As irrigation rates increased, the simulated crop water use supplied by the soil 

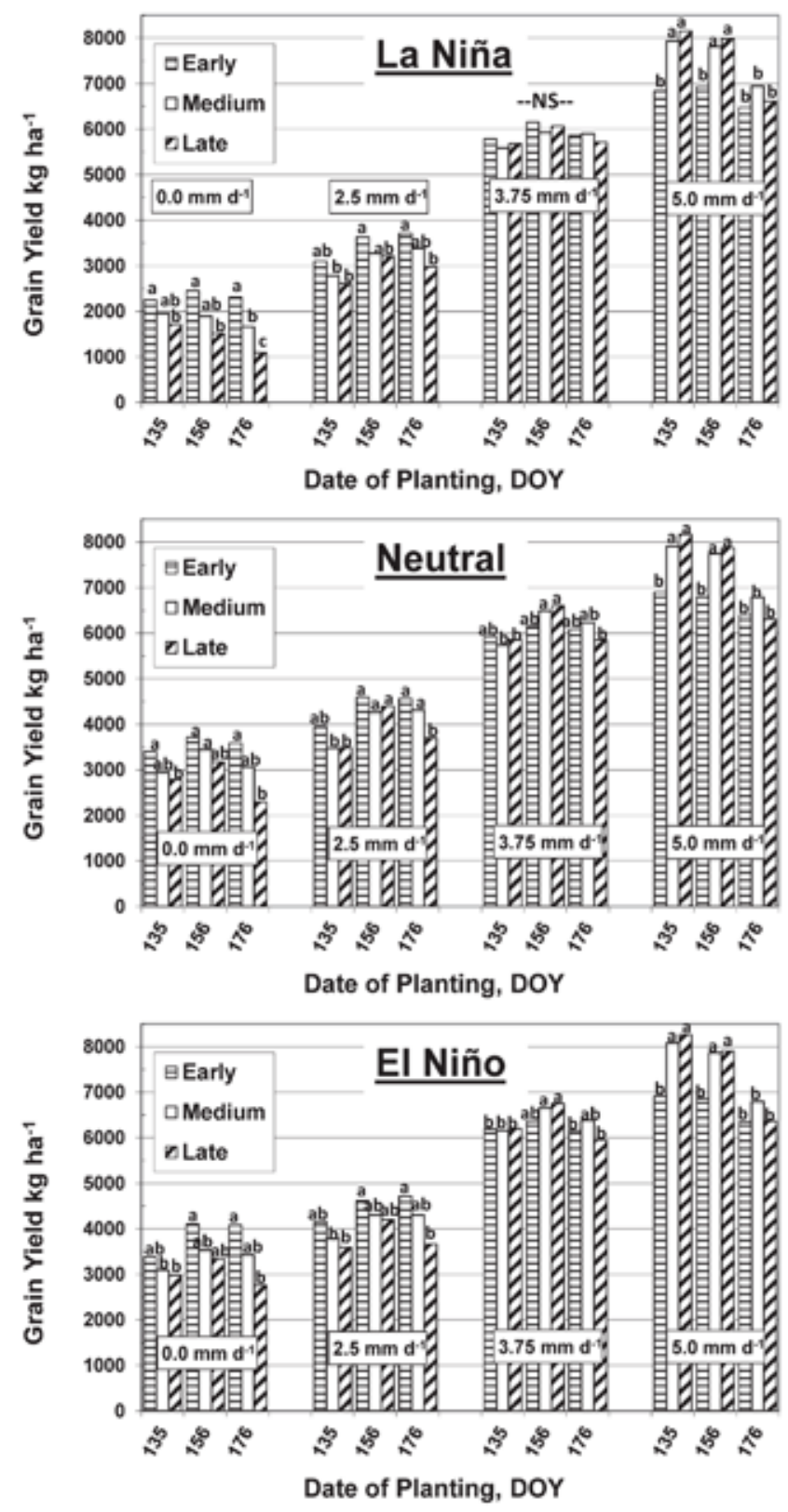

Fig. 3. Simulated (196|-2000) sorghum grain yield of early, medium, and late maturing cultivars planted on 15 May, 5 June, and 25 June (day of year [DOY] 135, I56, and 176) for dryland (rain only) and rain + deficit irrigation supplying up to $2.5,3.75$, and $5.0 \mathrm{~mm} \mathrm{~d}^{-1}$ during all El Niño southern oscillation phases. Columns from common irrigation levels with the same letter are not significantly different, $P=0.05$.

decreased from $35 \%$ for $2.50 \mathrm{~mm} \mathrm{~d}^{-1}$ to $26 \%$ for $3.75 \mathrm{~mm} \mathrm{~d}^{-1}$ and $10 \%$ for $5.00 \mathrm{~mm} \mathrm{~d}^{-1}$ regardless of ENSO phase.

\section{Grain Yield and Water Use Efficiency}

Water made available to a crop from the soil, rain, or irrigation generally determines the resulting yields in a semiarid climate with minimal runoff or drainage losses. A $50 \mathrm{~mm}$ increase in mean growing season precipitation for Neutral and El Niño phases compared with the La Niña phase in our simulations occurred despite maturing ENSO phase effects being less pronounced during the boreal summer. The resulting overall simulated sorghum grain yield averaged across irrigation, planting date, and cultivar maturity levels differed by ENSO phase, which ranged from the significantly $(P<0.01)$ lower of $4550 \mathrm{~kg}$ $\mathrm{ha}^{-1}$ for La Niña to $5140 \mathrm{~kg} \mathrm{ha}^{-1}$ for Neutral and $5290 \mathrm{~kg} \mathrm{ha}^{-1}$ for El Niño phases. This reflects greater precipitation during the Neutral and El Niño phases. Grain sorghum yield increased with increasing irrigation levels, but varied with ENSO phase (Fig. 3). For example, increasing the irrigation level from 0.00 to $2.50 \mathrm{~mm}$ $\mathrm{d}^{-1}$ improved La Niña dryland grain yields of $1870 \mathrm{~kg} \mathrm{ha}^{-1}$ by about $1300 \mathrm{~kg} \mathrm{ha}^{-1}$ to $3190 \mathrm{~kg} \mathrm{ha}^{-1}$ compared with more modest increases from $3160 \mathrm{~kg} \mathrm{ha}^{-1}$ to $4080 \mathrm{~kg} \mathrm{ha}^{-1}$ for the Neutral and from $3410 \mathrm{~kg} \mathrm{ha}^{-1}$ to $4150 \mathrm{~kg} \mathrm{ha}^{-1}$ for the El Niño phases (Table 2). At the $3.75 \mathrm{~mm} \mathrm{~d}^{-1}$ irrigation level, ENSO phase effects to increase grain yield diminished to $<450 \mathrm{~kg} \mathrm{ha}^{-1}$ over the $\mathrm{La}$ Niña $5850 \mathrm{~kg} \mathrm{ha}^{-1}$ low, ranging up to $6100 \mathrm{~kg} \mathrm{ha}^{-1}$ for Neutral and $6310 \mathrm{~kg} \mathrm{ha}^{-1}$ for El Niño phases. The ENSO phase had essentially no effect on simulated grain yield at the $5.00 \mathrm{~mm} \mathrm{~d}^{-1}$ irrigation rate and averaged $7260 \pm 45 \mathrm{~kg} \mathrm{ha}^{-1}$ across all phases.

Despite typically greater grain yield during wetter Neutral and El Niño phase years, the mean grain yield of late planted, DOY-176, sorghum was significantly $(P=0.05)$ lower than for the DOY-156 planting regardless of ENSO phase (Fig. 3) that we attributed, in part, to reduced growing season duration due to freeze events. An interaction of irrigation with planting date resulted from a shift in the consistently lowest yielding combination of DOY-176 planted sorghum irrigated with $5.00 \mathrm{~mm}$ $\mathrm{d}^{-1}$ to early, DOY-135, planted sorghum irrigated at lower rates of $2.50 \mathrm{~mm} \mathrm{~d}^{-1}$ and $3.75 \mathrm{~mm} \mathrm{~d}^{-1}$. Although sorghum grain yield did not vary significantly $(P>0.05)$ with cultivar maturity in contrast to findings in Nebraska by Garrity et al. (1982), our consistently higher yields of early cultivars with 0.00 or 2.50 $\mathrm{mm} \mathrm{d}^{-1}$ irrigation levels were similarly reversed by an interaction of higher-yielding late maturing cultivars that took advantage of the $5.00 \mathrm{~mm} \mathrm{~d}^{-1}$ irrigation (Fig. 3).

Plant use of the stored soil water, precipitation, and applied irrigation determines water use efficiency (WUE) and generally follows crop yield. Our calculated WUE for the La Niña phase of $0.85 \mathrm{~kg} \mathrm{~m}^{-3}$ was significantly $(P<0.01)$ lower than the $0.96 \pm 0.01 \mathrm{~kg} \mathrm{~m}^{-3}$ average of Neutral and El Niño phases that reflected their corresponding greater simulated yields since the range in total water use differed by only 6\% (Fig. 4). Our calculated WUE followed the greater grain yields resulting from increasing irrigation levels that averaged a peak $1.20 \pm 0.01 \mathrm{~kg}$ $\mathrm{m}^{-3}$ across all ENSO phases for the $5.00 \mathrm{~mm} \mathrm{~d}^{-1}$ irrigation that provided almost half of the water used by the crop. For sorghum receiving $3.75 \mathrm{~mm} \mathrm{~d}^{-1}$ irrigation, the La Niña phase WUE of $1.07 \mathrm{~kg} \mathrm{~m}^{-3}$ was numerically lower than the average WUE of $1.11 \pm 0.01 \mathrm{~kg} \mathrm{~m}^{-3}$ for the Neutral and El Niño phases and significantly $(P=0.05)$ lower than WUE of the $5.00 \mathrm{~mm} \mathrm{~d}^{-1}$ irrigation regardless of ENSO phase. Water use efficiency for sorghum receiving $2.50 \mathrm{~mm} \mathrm{~d}^{-1}$ irrigation increased from a low of $0.68 \mathrm{~kg} \mathrm{~m}^{-3}$ for La Niña up to $0.83 \mathrm{~kg} \mathrm{~m}^{-3}$ for the Neutral and $0.84 \mathrm{~kg} \mathrm{~m}^{-3}$ for the El Niño phases, indicating the greater impact of the additional precipitation on grain yield. The WUE of the $2.50 \mathrm{~mm} \mathrm{~d}^{-1}$ irrigation level was significantly different from the corresponding WUE at $3.75 \mathrm{~mm} \mathrm{~d}^{-1}$ for all ENSO phases. Dryland WUE for the drier La Niña phase averaged $0.43 \mathrm{~kg} \mathrm{~m}^{-3}$ compared with $0.66 \mathrm{~kg} \mathrm{~m}^{-3}$ and $0.73 \mathrm{~kg} \mathrm{~m}^{-3}$ for the Neutral and El Niño phases, respectively, and was unexpectedly less than long-term field estimates around $0.90 \mathrm{~kg} \mathrm{~m}^{-3}$ for sorghum (Jones and Popham, 1997; Baumhardt et al., 2017). 
Table 2. The 40-yr and El Niño southern oscillation-phase specific mean simulated yield of uniform application of irrigation capacities and the weighted-average yield for split-pivot application strategy combinations resulting in a fixed total irrigation capacity. The uniform irrigation strategy base yield of $3810 \mathrm{~kg} \mathrm{ha}^{-1}$ was from a fixed capacity deficit irrigation of $2.5 \mathrm{~mm} \mathrm{~d}^{-1}$.

\begin{tabular}{|c|c|c|c|c|c|}
\hline $\begin{array}{l}\text { Application } \\
\text { strategy }\end{array}$ & $\begin{array}{l}\text { Irrigation } \\
\text { capacity }\end{array}$ & $\begin{array}{l}\text { Simulated } \\
\text { yield }\end{array}$ & $\begin{array}{l}\text { Weighted } \\
\text { average yield }\end{array}$ & $\begin{array}{c}\text { Yield fraction, phase } \\
\text { specific uniform strategy }\end{array}$ & $\begin{array}{c}\text { Yield fraction, overall base } \\
\text { uniform strategy }\end{array}$ \\
\hline & $\mathrm{mm} \mathrm{d}^{-1}$ & +2 & & 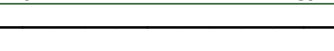 & 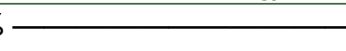 \\
\hline \multicolumn{6}{|l|}{ Overall } \\
\hline Uniform & 2.50 & 3810 & 3810 & 100 & 100 \\
\hline \multirow[t]{2}{*}{$2: 1$} & 3.75 & 6090 & 5000 & 131 & $|3|$ \\
\hline & Dryland & 2810 & & & \\
\hline \multirow[t]{2}{*}{$I: I$} & 5.00 & 7260 & 5040 & 132 & 132 \\
\hline & Dryland & 2810 & & & \\
\hline \multicolumn{6}{|l|}{ La Niña } \\
\hline Uniform & 2.50 & 3190 & 3190 & 100 & 84 \\
\hline \multirow[t]{2}{*}{$2: 1$} & 3.75 & 5850 & 4530 & 142 & 119 \\
\hline & Dryland & 1870 & & & \\
\hline \multirow[t]{2}{*}{ I:I } & 5.00 & 7300 & 4590 & 144 & 120 \\
\hline & Dryland & 1870 & & & \\
\hline \multicolumn{6}{|l|}{ Neutral } \\
\hline Uniform & 2.50 & 4080 & 4080 & 100 & 107 \\
\hline \multirow[t]{2}{*}{$2: 1$} & 3.75 & 6100 & 5120 & 125 & 135 \\
\hline & Dryland & 3160 & & & \\
\hline \multirow[t]{2}{*}{$\mathrm{I}: \mathrm{I}$} & 5.00 & 7210 & 5190 & 127 & 136 \\
\hline & Dryland & 3160 & & & \\
\hline \multicolumn{6}{|l|}{ El Niño } \\
\hline Uniform & 2.50 & 4150 & 4150 & 100 & 109 \\
\hline \multirow[t]{2}{*}{$2: 1$} & 3.75 & 6310 & 5350 & 129 & 140 \\
\hline & Dryland & 3410 & & & \\
\hline \multirow[t]{2}{*}{ I:I } & 5.00 & 7270 & 5340 & 129 & 140 \\
\hline & Dryland & 3410 & & & \\
\hline
\end{tabular}

The simulated sorghum WUE averaged across ENSO phase and irrigation level for planting dates DOY-135 at $0.87 \mathrm{~kg} \mathrm{~m}^{-3}$ was significantly $(P=0.05)$ lower than the 0.95 and $0.94 \mathrm{~kg}$ $\mathrm{m}^{-3}$ for DOY-156 or DOY-176, although the WUE within each ENSO phase repeated that planting date ranking (Fig. 4). Progressively later maturing cultivars produced incrementally lower WUE values that were significantly $(P=0.05)$ different for each ENSO phase. That is, La Niña phase WUE early, medium, and late maturing cultivars averaged $0.93 \mathrm{~kg} \mathrm{~m}^{-3}$, $0.84 \mathrm{~kg} \mathrm{~m}^{-3}$, and $0.78 \mathrm{~kg} \mathrm{~m}^{-3}$, respectively, while the corresponding Neutral and El Niño phase WUE values averaged $1.02 \pm 0.01 \mathrm{~kg} \mathrm{~m}^{-3}, 0.96 \pm 0.01 \mathrm{~kg} \mathrm{~m}^{-3}$, and $0.89 \pm 0.01 \mathrm{~kg}$ $\mathrm{m}^{-3}$. The significant $(P<0.01)$ interaction between cultivar maturity and irrigation level was manifested by a decreasing difference in WUE shown in Fig. 4 for progressively later maturing cultivars as the irrigation level increased from 0.00 to $3.75 \mathrm{~mm}$ $\mathrm{d}^{-1}$ and dissipated with $5.00 \mathrm{~mm} \mathrm{~d}^{-1}$ irrigation. This was attributed to early maturing cultivars sacrificing yield potential by limiting the crop canopy and accumulated biomass to expedite grain production in contrast with later maturing cultivars that emphasize biomass accumulation to exploit resources including water available from irrigation and rain during longer growing seasons to maximize grain yield.

The ratio of grain to biomass or the harvest index, HI, may clarify differences in the WUE that improves as the amount of grain produced per unit of water used increases. Factors interfering with normal maturing of grain typically depress HI, which was observed for the growing season limiting DOY-176 planting date, $\mathrm{HI}$ of 0.39 , that was significantly $(P=0.05)$ less than the 0.42 mean HI for both DOY-135 and DOY-156 plantings (Fig. 5.). The HI consistently decreased with progressively later maturing cultivars, averaging 0.45 across ENSO phases for early cultivars compared with significantly $(P=0.05)$ different values of 0.41 and 0.36 for the medium and late maturing cultivars. Those cultivar maturity effects, however, were most striking at the dryland and $2.50 \mathrm{~mm} \mathrm{~d}^{-1}$ irrigation levels because water availability limited panicle, seed number, and seed mass development (data not shown). Water deficit stress that limits crop development and subsequent production of harvestable grain contributed to the significantly lower $\mathrm{HI}$ of 0.39 for La Niña compared with 0.42 for the wetter Neutral and El Niño phases. Our simulated HI generally increased as irrigation increased sufficiently to offset critical crop water demand regardless of ENSO phase, averaging 0.34 for dryland, 0.41 for $2.50 \mathrm{~mm} \mathrm{~d}^{-1}, 0.45$ for $3.75 \mathrm{~mm} \mathrm{~d}^{-1}$, and 0.44 for $5.00 \mathrm{~mm} \mathrm{~d}^{-1}$ levels. In fact, the mean $\mathrm{HI}$ of the 3.75 - and 5.00- $\mathrm{mm} \mathrm{d}^{-1}$ irrigation levels within all three ENSO phase combinations was 0.44 , suggesting limited water stress for the higher irrigation levels.

\section{Irrigation Strategies and Management Considerations}

We compared sorghum grain yields for three irrigation strategies that spread a fixed water resource over an area that was (i) uniformly deficit irrigated at $2.50 \mathrm{~mm} \mathrm{~d}^{-1}$, or concentrates that water on a partitioned area irrigated at rates of (ii) $3.75 \mathrm{~mm} \mathrm{~d}^{-1}$ and dryland in a 2:1 ratio, or (iii) $5.00 \mathrm{~mm} \mathrm{~d}^{-1}$ and dryland in a 1:1 ratio. Grain sorghum yields averaged across planting date and cultivar maturity for dryland and 2.50-, 3.75-, and 5.00-mm 

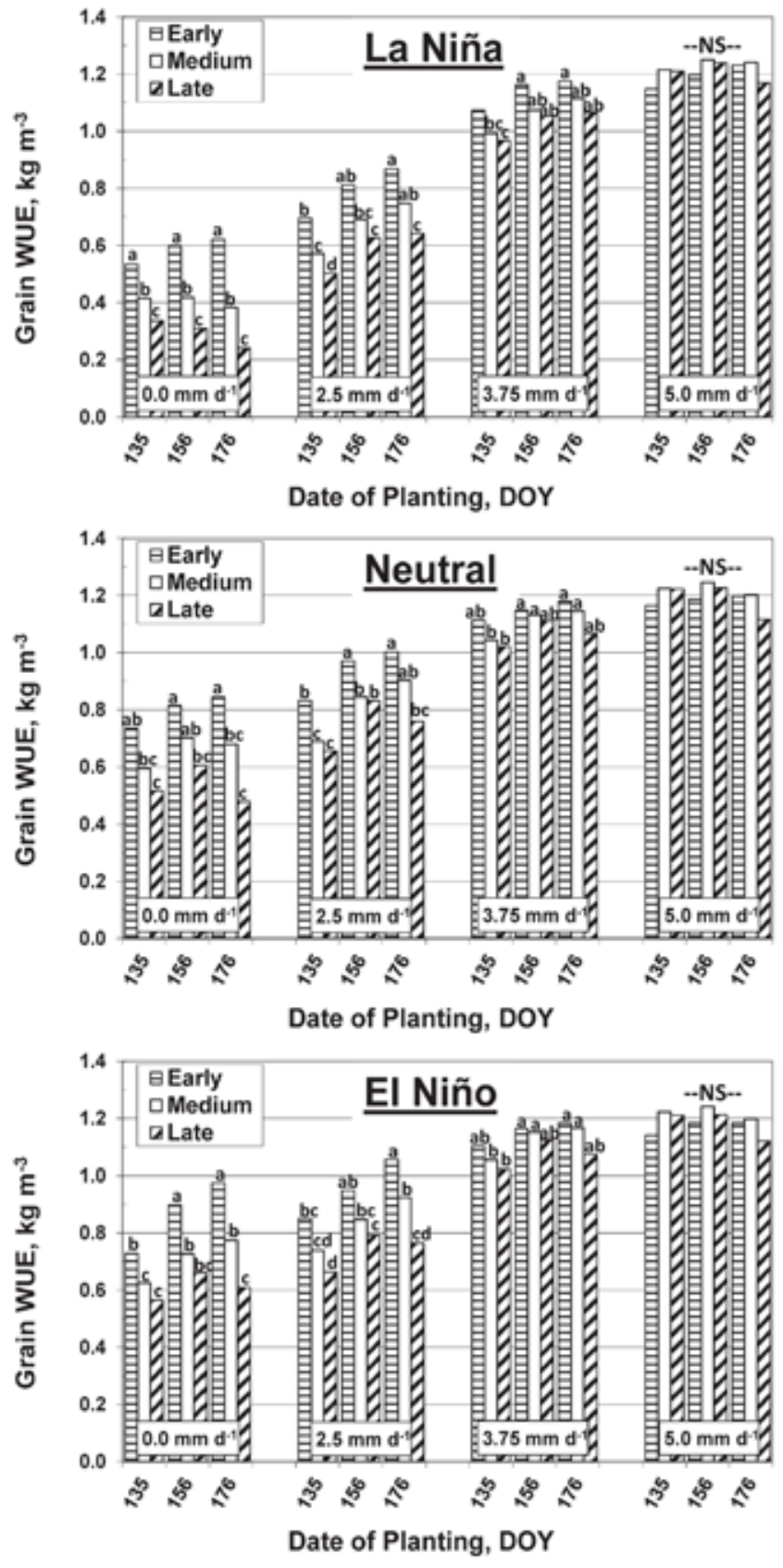

Fig. 4. Calculated grain sorghum water use efficiency (WUE) of early, medium, and late maturing cultivars planted on day of year (DOY) 135, 156, and 176 for dryland (rain only) and rain + deficit irrigation supplying up to $2.5,3.75$, and $5.0 \mathrm{~mm} \mathrm{~d}^{-1}$ during all El Niño southern oscillation phases. Columns from common irrigation levels with the same letter are not significantly different, $P=0.05$.

$\mathrm{d}^{-1}$ irrigation levels are listed for the overall 40-yr simulation and by ENSO phase specific years with the weighted averages for irrigation strategies using uniform or the $2: 1$ or 1:1 partitioning in Table 2. The overall simulated mean grain sorghum yield of the $2.50 \mathrm{~mm} \mathrm{~d}^{-1}$ uniformly irrigated area averaged $3810 \mathrm{~kg} \mathrm{ha}^{-1}$, which we used as the $100 \%$ yield base for comparison. Weighted yield averages for areas partitioned into a 2:1 or 1:1 ratio of irrigation to dryland increased $\sim 30 \%$ over the base yield to 5000 - or $5040-\mathrm{kg} \mathrm{ha}^{-1}$ and mirrored the partitioned irrigation yield advantage reported by Baumhardt et al. (2007).
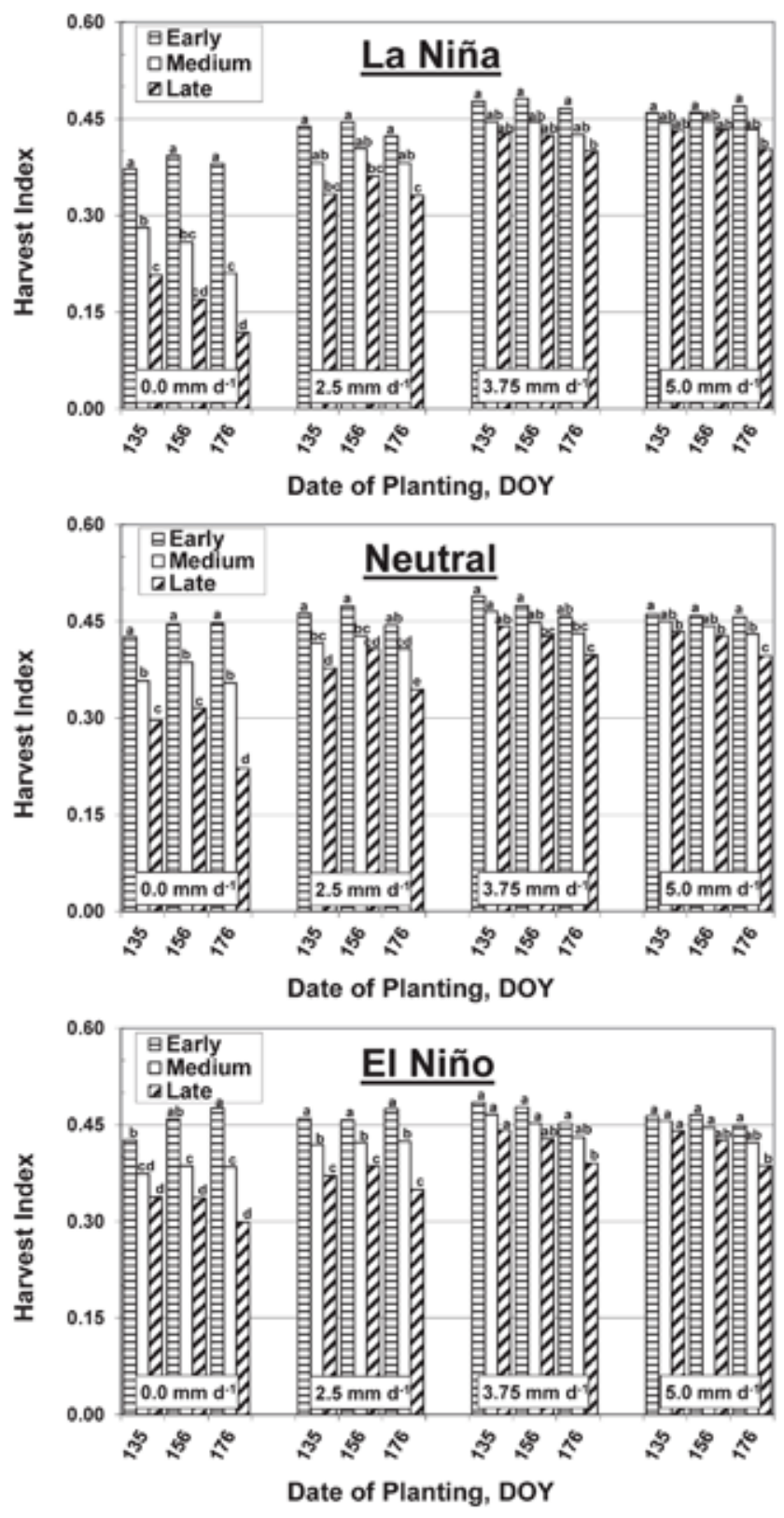

Fig. 5. Calculated grain sorghum harvest index (HI) of early, medium, and late maturing cultivars planted on day of year (DOY) 135, 156, and 176 for dryland (rain only) and rain + deficit irrigation supplying up to $2.5,3.75$, and $5.0 \mathrm{~mm} \mathrm{~d}^{-1}$ during all El Niño southern oscillation phases. Columns from common irrigation levels with the same letter are not significantly different, $P=0.05$.

The lower simulated average grain yields specific to the drier La Niña years were approximately $620 \mathrm{~kg} \mathrm{ha}^{-1}$ less than the overall mean of the uniform $2.50 \mathrm{~mm} \mathrm{~d}^{-1}$ irrigation or 3190 $\mathrm{kg} \mathrm{ha}^{-1}$, which was $84 \%$ of the overall base yield (Table 2). Likewise, mean La Niña yields from areas with partitioned irrigated to dryland ratios of 2:1 or 1:1 were 4530 - or $4590-\mathrm{kg}$ $\mathrm{ha}^{-1}$ that averaged $43 \%$ more than with uniform irrigation, but represent a modest $20 \%$ increase over the $3810 \mathrm{~kg} \mathrm{ha}^{-1}$ base yield. Increased rain for Neutral and El Niño phase years contributed to greater uniformly irrigated yields, averaging 4080 $\mathrm{kg} \mathrm{ha}^{-1}$ and $4150 \mathrm{~kg} \mathrm{ha}^{-1}$ or about $8 \%$ more than the base yield. Simulated 2:1 or 1:1 partitioned yields during Neutral phase years ranged from 5120 to $5190 \mathrm{~kg} \mathrm{ha}^{-1}$, respectively, or $26 \%$ 
more than with uniform irrigation, but 36\% more than the base yield. Similarly, the 2:1 and 1:1 partitioned average yield of 5345 $\pm 5 \mathrm{~kg} \mathrm{ha}^{-1}$ for El Niño years exceeded the phase specific uniform irrigation by 29 or $40 \%$ greater than the base. Although grain yields increased during wetter Neutral and El Niño phase years compared with those of La Niña, we identified no differences for yield optimization between either partitioning strategies regardless of the ENSO phase.

In lieu of irrigation to promote timely crop establishment, delayed planting of dryland crops due to unsuitable soil water conditions is an eventuality that often delays physiological maturity and increases production risk due to freeze injury. Sorghum freeze injury was simulated for $22 \%$ of all possible planting date, irrigation, and cultivar maturity combinations evaluated during the 40 test years. While all compared planting dates were subject to freeze injury prior to physiological maturity, freeze injuries were more frequent, $17 \%$ overall, for the late, DOY-176, planting date regardless of ENSO phase and should be avoided. The late maturing cultivar sustained freeze injury during $12 \%$ of all simulations compared with 8 and $2 \%$ for medium and early maturity cultivars and represent a risk reducing option under deficit irrigation. Dryland production often extended the growing season and sustained more frequent freeze injury, $9 \%$ overall during the $40 \mathrm{yr}$ evaluated. For regions with need of cattle forage, sorghum freeze injury may be reduced by "haying out" the crop with an earlier harvest near anthesis and reduced affected crops to $2.6 \%$ of our simulations that were exclusively dryland.

\section{SUMMARY AND CONCLUSIONS}

Our results showed a significant $(P<0.01) 50 \mathrm{~mm}$ increase in mean growing season rain during Neutral and El Niño phases over the La Niña phase during the 1961-2000 simulated growing seasons. This paralleled a trend described by Baumhardt et al. (2016) even though ENSO phase effects are less pronounced during the boreal summer. Dryland, $0.00 \mathrm{~mm}$ $\mathrm{d}^{-1}$ irrigation, and late maturing cultivar scenarios extended the growing season that in addition to late, DOY-176, planting resulted in more frequent freeze injury regardless of ENSO phase. Simulated grain yield increased significantly $(P<0.01)$ in response to greater rain during Neutral and El Niño than for La Niña phases and because of progressively higher irrigation levels that increased seasonal water use. The corresponding WUE also improved as irrigation level increased, but the drier La Niña phase generally depressed WUE. Although precipitation during the wetter Neutral and El Niño ENSO phases contributed up to $50 \%$ of seasonal water use, we observed that for increasing irrigation levels the seasonal water use supplied by rain decreased to $33 \%$ for the La Niña and $43 \%$ on average for Neutral and El Niño phases. The increasing irrigation levels, likewise, reduced the soil water contribution to crop water use from $41 \%$ for dryland to $10 \%$ for full irrigation regardless of ENSO phase.

Management practices that conserve irrigation water by utilizing more precipitation stored as soil water or received during the growing season can potentially extend the useful life of the Ogallala aquifer. We conclude that, uniformly irrigating an area at $2.5 \mathrm{~mm} \mathrm{~d}^{-1}$ with a fixed water resource yielded less grain than concentrating that water resource to irrigate an area partitioned 2:1 at $3.75 \mathrm{~mm} \mathrm{~d}^{-1}$ and dryland or $1: 1$ at $5.0 \mathrm{~mm} \mathrm{~d}^{-1}$ and dryland because of more efficient water use. In lieu of any significant cumulative yield difference between either partitioning strategy regardless of the ENSO phase, the optimal partitioning strategy would depend on the site-specific production constraints and economics.

\section{REFERENCES}

Baumhardt, R.L., and T.A. Howell. 2006. Seeding practices, cultivar maturity, and irrigation effects on simulated grain sorghum yield. Agron. J. 98:462-470. doi:10.2134/agronj2005.0156

Baumhardt, R.L., S.A. Mauget, P.H. Gowda, D.K. Brauer, and G.W. Marek. 2015. Optimizing cotton irrigation strategies as influenced by El Niño Southern Oscillation. Agron. J. 107:1895-1904. doi:10.2134/agronj14.0471

Baumhardt, R.L., S.A. Mauget, R.C. Schwartz, and O.R. Jones. 2016. El Niño southern oscillation effects on dryland crop production in the Texas High Plains. Agron. J. 108:736-744. doi:10.2134/ agronj2015.0403

Baumhardt, R.L., and J. Salinas-Garcia. 2006. Dryland agriculture in Mexico and the U.S. Southern Great Plains. In: G.A. Peterson et al., editors, Dryland agriculture. 2nd ed. Agron. Monogr. 23. ASA, CSSA, and SSSA, Madison, WI. p. 341-364. doi:10.2134/ agronmonogr23.2ed.c10

Baumhardt, R.L., R.C. Schwartz, O.R. Jones, B.R. Scanlon, R.C. Reedy, and G.W. Marek. 2017. Long-term conventional and no-tillage effects on field hydrology and yields of a dryland crop rotation. Soil Sci. Soc. Am. J. 81:200-209. doi:10.2136/sssaj2016.08.0255

Baumhardt, R.L., J.A. Tolk, T.A. Howell, and W.D. Rosenthal. 2007. Sorghum management practices suited to varying irrigation strategies: A simulation analysis. Agron. J. 99:665-672. doi:10.2134/ agronj2006.0092

Baumhardt, R.L.,J.A. Tolk, and S.R. Winter. 2005. Seeding practices, and cultivar maturity effects on simulated grain sorghum yield. Agron. J. 97:935-942. doi:10.2134/agronj2004.0087

Bell, J.M., R.C. Schwartz, K.J. McInnes, T.A. Howell, and C.L. Morgan. 2018. Deficit irrigation effects on yield and yield components of grain sorghum. Agric. Water Manage. 203:289-296. doi:10.1016/j. agwat.2018.03.002

Colaizzi, P.D., P.H. Gowda, T.H. Marek, and D.O. Porter. 2009. Irrigation in the Texas High Plains: A brief history and potential reductions in demand. Irrig. Drain. 58:257-274. doi:10.1002/ird.418

CPC. 2018. Historical El Niño/La Niña episodes (1950-present) Cold and warm episodes by season. Climate Prediction Ctr. http://www. cpc.ncep.noaa.gov/products/analysis_monitoring/ensostuff/ensoyears.shtml (accessed 4 Sept. 2018).

Darbonne, N. 2018. Devon evaluating 'Two Monster' Delaware basin wells. Oil and gas investor, Hart Energy. https://www.oilandgasinvestor.com/devon-energy-delaware-basin-monster-wells-DUGPermian-1705541 (accessed 19 Sept. 2018).

Dieter, C.A., M.A. Maupin, R.R. Caldwell, M.A. Harris, T.I. Ivahnenko, J.K. Lovelace, N.L. Barber, and K.S. Linsey. 2018. Estimated use of water in the United States in 2015: U.S. Geological Survey Circular 1441. doi:10.3133/cir1441.

Donatelli, M., G.L. Hammer, and R.L. Vanderlip. 1992. Genotype and water limitation effects on phenology, growth, and transpiration efficiency in grain sorghum. Crop Sci. 32:781-786. doi:10.2135/cropsci 1992.0011183X003200030041x

Farré, I., and J. María Faci. 2006. Comparative response of maize (Zea mays L.) and sorghum (Sorghum bicolor L. Moench) to deficit irrigation in a Mediterranean environment. Agric. Water Manage. 83:135-143. doi:10.1016/j.agwat.2005.11.001

Follett, R.F., C.E. Stewart, E.G. Pruessner, and J.M. Kimble. 2012. Effects of climate change on soil carbon and nitrogen storage in the US Great Plains. J. Soil Water Conserv. 67:331-342. doi:10.2489/ jswc.67.5.331 
Garrity, D.P., D.G. Watts, C.Y. Sullivan, and J.R. Gilley. 1982. Moisture deficits and grain sorghum performance: Effect of genotype and limited irrigation strategy. Agron. J. 74:808-814. doi:10.2134/agronj19 $82.00021962007400050010 \mathrm{x}$

Gerik, T., B. Bean and R. Vanderlip. 2003. Sorghum growth and development. Texas Cooperative and Extension Publ. B-6137. Texas Coop. Ext., College Station, TX.

Gutentag, E.D., F.J. Heimes, N.C. Krothe, R.R. Luckey, and J.B. Weeks. 1984. Geohydrology of the High Plains aquifer in parts of Colorado, Kansas, Nebraska, New Mexico, Oklahoma, South Dakota, Texas, and Wyoming. USGS Professional Pap. 1400-B. U.S. Gov. Print. Office, Washington, DC.

Hauser, V.L., and O.R. Jones. 1991. Runoff curve numbers for the Southern High Plains. Trans. ASAE 34:142-148. doi:10.13031/2013.31636

Heiniger, R.W., R.L. Vanderlip, S.M. Welch, and R.C. Muchow. 1997. Developing guidelines for replanting grain sorghum: II. Improved methods of simulating caryopsis weight and tiller number. Agron. J. 89:84-92. doi:10.2134/agronj1997.00021962008900010013x

Howell, T.A. 2001. Enhancing water use efficiency in irrigated agriculture. Agron. J. 93:281-289. doi:10.2134/agronj2001.932281x

Howell, T.A., K.S. Copeland, A.D. Schneider, and D.A. Dusek. 1989. Sprinkler irrigation management for corn- Southern Great Plains. Trans. ASAE 32:147-154, 160. doi:10.13031/2013.30974

Jones, J.W., J.W. Hansen, F.S. Royce, and C.D. Messina. 2000. Potential benefits of climate forecasting to agriculture. Agric. Ecosyst. Environ. 82:169-184. doi:10.1016/S0167-8809(00)00225-5

Jones, O.R., and T.W. Popham. 1997. Cropping and tillage systems for dryland grain production in the Southern High Plains. Agron. J. 89:222-232. doi:10.2134/agronj1997.00021962008900020012x

Mauget, S.A., and D.R. Upchurch. 1999. El Niño and La Niña related climate and agricultural impacts over the Great Plains and Midwest. J. Prod. Agric. 12:203-215. doi:10.2134/jpa1999.0203

Mauget, S., J. Zhang, and J. Ko. 2009. The value of ENSO forecast information to dual-purpose winter wheat production in the U.S. southern High Plains. J. Appl. Meteorol. Climatol. 48:2100-2117. doi:10.1175/2009JAMC2018.1

McCabe, G.J., J.L. Betancourt, and S. Feng. 2015. Variability in the start, end, and length of frost-free periods across the conterminous United States during the past century. Int. J. Climatol. 35:4673-4680. doi:10.1002/joc.4315

McGuire, V.L. 2017. Water-level and recoverable water in storage changes, High Plains Aquifer, predevelopment to 2015 and 2013-2015. USGS Sci. Investigations Rep. 2017-5040. USGS, Reston, VA.
Moroke, T.S., R.C. Schwartz, K.W. Brown, and A.S.R. Juo. 2005. Soil water depletion and root distribution of three dryland crops. Soil Sci. Soc. Am. J. 69:197-205. doi:10.2136/sssaj2005.0197

Nair, S., S. Maas, C. Wang, and S. Mauget. 2013. Optimal field partitioning for center-pivot-irrigated cotton in the Texas High Plains. Agron. J. 105:124-133. doi:10.2134/agronj2012.0219

Rosenthal, W.D., and T.J. Gerik. 1990. Application of a crop growth model to evaluate cultural practices and optimize dryland grain sorghum yield. J. Prod. Agric. 3:124-131. doi:10.2134/jpa1990.0124

Rosenthal, W.D., R.L. Vanderlip, G.F. Arkin, and B.S. Jackson. 1989. SORKAM: A grain sorghum crop growth model. Mp-1699. Texas Agric. Exp. Stn., College Station.

SAS Institute. 2014. SAS Version 9.4. User's Guide. SAS Inst. Inc., Cary, NC.

Scanlon, B.R., R.C. Reedy, F. Male, and M. Walsh. 2017. Water issues related to transitioning from conventional to unconventional oil production in the Permian Basin. Environ. Sci. Technol. 51:1090310912. doi:10.1021/acs.est.7b02185

Steiner, J.L. 1989. Tillage and surface residue effects on evaporation from soils. Soil Sci. Soc. Am. J. 53:911-916. doi:10.2136/ sssaj1989.03615995005300030046x

Stewart, B.A. 2003. Aquifers, Ogallala. In: B.A. Stewart and T.A. Howell, editors, Encyclopedia of water science. Marcel-Dekker, NY. p. 43-44.

Stichler, C., M. McFarland, and C. Coffman. 1997. Irrigated and dryland grain sorghum production south and southwest Texas. B-6048. Texas Coop. Ext., College Station, TX.

Tolk, J.A., and T.A. Howell. 2001. Measured and simulated evapotranspiration of grain sorghum grown with full and limited irrigation in three High Plains soils. Trans. ASAE 44:1553-1558.

Vanderlip, R., K. Roozeboom, D. Fjell, J. Shroyer, H. Kok, D. Regehr, D. Whintey, D.H. Rogers, M. Alam, D. Jardine, H.L. Brooks, R.K. Taylor, J.P. Harner, and L.N. Langemeier. 1998. Grain sorghum production handbook. C-687 p. 31. Kansas State Univ. Agric. Exp. Stn. And Coop Ext. Serv. Manhattan, KS.

Wagner, K. 2012. Status and trends of irrigated agriculture in Texas: A special report. TWRI EM-115 p. 6. Texas Water Resources Institute, College Station, TX.

Xie, Y., J.R. Kiniry, V. Nedbalek, and W.D. Rosenthal. 2001. Maize and sorghum simulations with CERES-Maize, SORKAM, and ALMANAC under water-limiting conditions. Agron. J. 93:11481155. doi:10.2134/agronj2001.9351148x 